\title{
KONSEP PERFORMANCE BAHASA MINANGKABAU DALAM NOVEL
}

Performance Concept of Minangkabau Language in Novels

${ }^{a}$ Wahyudi Rahmat, ${ }^{\text {b}}$ Yolanda Z. Putri, ${ }^{\mathrm{c}}$ Winci Firdaus

${ }^{a, b}$ STKIP PGRI Sumatera Barat

'Badan Pengembangan dan Pembinaan Bahasa

wahyudirahmat24@gmail.com ${ }^{a}$,yolandazputri@yahoo.com ${ }^{b}$,wincifirdausoke@gmail.com ${ }^{c}$

\begin{abstract}
Abstrak
Masalah dalam penelitian ini mengkaji tentang bentuk performance atau cerminan dari sistem bahasa yang ada pada pikiran penutur dalam novel Jemput Terbawa karya Pinto Anugrah. Performance dalam sebuah novel layak untuk diteliti dengan tujuan untuk mengetahui bentuk pemakaian bahasa penutur atau Pinto Anugrah sebagai pengarang untuk menyampaikan maksud ke dalam sebuah karyanya. Oleh karena itu, tujuan analisis ini adalah untuk melihat bagaimana bentuk performance bahasa minangkabau Pinto Anugrah yang dipengaruhi oleh psikologi dan kebudayaan yang memengaruhinya. Teori yang digunakan dalam penelitian ini adalah Simanjuntak (2015). Metode penelitian yang digunakan menggunakan adalah metode simak atau menyimak teks dan menandai isi dari teks dengan teknik catat. Analisis datanya menggunakan metode padan dan metode agih. Semua bentuk ini didasarkan pada pendapat Sudaryanto (1993). Hasil penelitian ini menemukan bahwa bentuk performance dalam novel Jemput Terbawa dapat dilihat dalam beberapa bentuk yakni bentuk dendang, rabab, lusuah, cigak baruak, dan rabab jua.
\end{abstract}

Kata-kata kunci: performance, bahasa, novel

\begin{abstract}
The problem in this study examines the form of performance or reflection of the language system that is on the mind of the speaker in Pinto Anugrah's novel Jemput Terbawa. Performance in a novel deserves to be researched with the aim of knowing the form of the use of speaker language or Pinto Anugrah as an author to convey the intent into a work. Therefore, the purpose of this analysis is to see how the form of performance of pinto anugrah minangkabau language that is influenced by psychology and culture that affects it. The theory used in this study is Simanjuntak (2015). The research method used is the method of listening to or listening to the text and marking the content of the text with a note technique. The data analysis uses the padan method and agih method. All of these forms are based on the opinion of Sudaryanto (1993). The results of this study found that the form of performance in the novel Jemput Terbawa can be seen in several forms, namely the form of dendang, rabab, lusuah, cigak baruak, and rabab jua.
\end{abstract}

Keywords: performance, language, novel

How to Cite: Rahmat, Wahyudi, Yolanda Z. Putri, dan Winci Firdaus. (2021). Konsep Performance Bahasa Minangkabau dalam Novel. Ranah: Jurnal Kajian Bahasa. 10(1). 170-181. doi: https://doi.org/10.26499/rnh.v10i1.2120 


\section{PENDAHULUAN}

Secara umum, performance dalam bahasa menurut Simanjuntak (2015) merupakan penggunaan bahasa secara nyata dalam situasi komunikasi yang sebenarnya merupakan cerminan dari sistem bahasa yang ada pada pikiran penutur, yang dimaksud penutur di sini ialah seorang pengarang. Bentuk performance dalam pikiran penutur biasanya dilatarbelakangi oleh pengaruh budaya dan psikologis penutur tersebut. Pengaruh psikologis dalam berbahasa juga memengaruhi apa yang disampaikan atau dituturkan. Hal ini sesuai dengan pendapat (Revita, Trioclarise, and Anggreiny, 2019) yang menyatakan bahwa secara psikologis, penggunaan berbagai tindak tutur dalam komunikasi sepenuhnya bergantung pada situasi mental para penutur. Sejalan dengan itu (Rahmat, Revita, and Fitriyah, 2019) menyatakan bahwa proses berbahasa dalam berkomunikasi merupakan perwujudan dalam pikiran seseorang yang disampaikan dalam beberapa bentuk aktivitas pada proses penyampaian ide dan pikiran. Berdasarkan hal itu, maka hubungannya dalam pengarang, bentuk performance ini lebih menekankan kepada pemakaian bahasa daerah pengarang tersebut dalam karyanya, karena sebagaian besar bahasa dipengaruhi oleh lingkungan dan kebudayaan yang dianut oleh si penutur. Oleh sebab itu, untuk mengetahui bentuk performance dalam sebuah karya sastra seorang pengarang, dapat dilihat dari bentuk lokalitas kebahasaan daerah pengarang.

Lokalitas merupakan konsep umum yang berkaitan dengan tempat tertentu berbatas atau dibatasi oleh wilayah lain. Suatu daerah memiliki ciri khas yang berbeda satu sama lainnya, seperti Minangkabau identik mempunyai bahasa sendiri yang dinamakan bahasa Minangkabau. Bahasa Minangkabau terdiri dari bahasa lisan dan bahasa tulisan yang kerap digunakan oleh seorang pengarang dalam menghasilkan sebuah karya. Warna lokal atau istilah lokalitas yang digunakan oleh pengarang dalam karya sastra bisa membuka sebuah pintu masuk bagi pembaca untuk memahami kebudayaan Minangkabau yang terutama bahasanya. Lokalitas dalam penelitian ini tidak membicarakan tentang kebudayaan dan psikologis yang mempengaruhi, tapi mentitikberatkan ke unsur kebahasaan yang digunakan oleh pengarang dalam karyanya hingga menjadi ciri khas atau karakter pengarang. Maka itu, penelitian ini menjadi menarik untuk diteliti.

Seorang pengarang bernama Pinto Anugrah menempatkan lokalitas Sumatra Barat sebagai warna lokal kebahasaan dalam karyanya, yaitu novel Jemput Terbawa. Warna lokal kebahasaan yang digunakan dalam novel Jemput Terbawa ialah bahasa Minangkabau yang dapat diketahui melalui kutipan-kutipan di dalam novel ini. Hal ini terlihat bahwa novel Jemput Terbawa sangat kental dengan atmosfer kebudayaan Minangkabau mulai dari bahasa, penamaan tokoh, daerah, hingga adanya dua legenda yang sudah tak asing lagi bagi masyarakat Minangkabau. Lokalitas juga merupakan proses pemaknaan atas sebuah bahasa yang tersurat di dalam novel Jemput Terbawa.

Lokalitas dalam novel Jemput Terbawa harus dimaknai sebagai ruang kultural yang dinamis dan tidak pernah berhenti pada makna tertentu ketika melekat pada bahasa, khususnya pada teks. Teks sastra merupakan sebuah bahasa yang bermuara pada ruang imajinasi pembaca. Hal ini dapat dilihat dari beberapa kutipan yang ada dalam novel Jemput Terbawa seperti rebab, kaba, sanak, lampu togok, lasak, cigak baruak, bundo kanduang, tukak, dikubak, dan kuncun. Oleh sebab itu, imajinasi pembaca sangat menentukan proses pemaknaan sebuah bahasa Minangkabau yang dihadirkan oleh pengarang dalam karya sastra. Semi (2002) menyatakan pemakaian bahasa dalam sastra mengandung dimensi yang amat luas. Ia tidak hanya sebagai sarana penyampaian gagasan atau tema kepada pembaca, tetapi lebih dari itu. Pemakaian istilah lokal kadang-kadang memang lebih ekpresif seperti leksikon dan idiom. Dengan demikian, terasa adanya penguatan setting cerita yang berlangsung di daerah, seperti tukang kaba, kuncun, mengeak, tresno, sampean dan lain-lain. 
Beberapa penelitian yang telah membahas tentang performance adalah Sitompul dan Simaremar (2017) yang membahas mengenai analisis fungsi, nilai budaya, dan kearifan lokal dalam film Sinamot karya sineas muda Medan. Dalam penelitiannya Sitompul dan Simaremar melihat fungsi, nilai budaya, dan kearifan lokal dari perilaku berbahasa sineas muda dalam sebuah film. Dalam artikelnya mereka menyebutkan bahwa pemahaman struktur teks dan konteks dalam sebuah teks atau naskah film dapat memberikan pemahaman tentang bentuk dari performance tradisi lisan, sehingga mampu merumuskan struktur teks dan konteks (bentuk) tradisi lisan, serta menggali nilai, norma, dan kearifan lokal dalam film tersebut. Selanjutnya, Lubis (2019) dalam penelitiannya membahas tentang tradisi lisan nandong Simeulue, menyebutkan bahwa konsep performance dapat memperjelas konsep tentang kreatifitas penutur untuk menemukan keunikan nandong dalam masyarakat Simeulue dan mendapatkan ideologi serta kekuatan dalam bahasanya. Selain itu sebagai wujud performance dalam karya sastra dalam hal ini adalah tergambar dari lokalitas. Beberapa penelitian yang membahas tentang lokalitas di antaranya adalah Rinaldi (2018), Yulianto (2017) dan Jumadi (2017), menyebutkan bahwa untuk melihat bentuk performance dalam lokalitas kebahasaan, sangat diperlukan guna mengungkap atau memunculkan bentuk-bentuk kebahasaan daerah yang menjadi ciri pembeda dengan karya sastra yang lain. Seperti penggunaan istilah, penamaan daerah, benda-benda kedaerahan, dan lain sebagainya. Oleh sebab itu, penelitian mengenai bentuk performance ini menjadi menarik dan layak untuk diteliti guna melihat seperti apa bentuk performance dalam lokalitas novel Jemput Terbawa karya Pinto Anugrah.

\section{LANDASAN TEORI \\ Performance}

Lokalitas bisa juga disebut dengan warna lokal yang dimana terdapat penggunaan bahasa daerah. Lokalitas dalam antropolinguistik merupakan peristiwa pemaknaan bahasa yang dilihat dari unsur kebudayaan dan kebahasaan. Dalam kajian antropolinguistik, kajian ini membahas tentang kebudayaan dan bahasa yang saling berhubungan. Duranti (Simanjuntak, n.d. 2015) menyatakan bahwa untuk melihat bentuk lokalitas dalam antropolinguistik dapat dilihat dari beberapa gagasan analisis, yaitu (1) performance, merupakan penggunaan bahasa secara nyata dalam dalam situasi komunikasi yang sebenarnya merupakan cerminan dari sistem bahasa yang ada pada pikiran penutur, (2) indexcality (indeksikalitas) menyangkut tanda yang memiliki hubungan eksitensial dengan yang diacu oleh penutur, (3) partisipation, keterlibatan penutur dalam menghasilkan tuturan yang berterima. Simajuntak (2015) mengatakan bahwa bahwa konsep performance adalah terminologi kunci dalam tata bahasa generatif yang dikembangkan oleh salah satu ahli Noem Chomsky pada tahun 1965.

Sibarani (2015) menyatakan antropolinguistik mempelajari wujud bahasa sebagai jalan masuk (the entry point) dalam kajian kebudayaan sehingga, bahasa dapat dijadikan sebagai alat untuk menggali kebudayaan dan aspek-aspek lain kehidupan manusia itu secara menyeluruh. Secara umum, salah satu bentuk aspek-aspek lain kehidupan manusia itu adalah penggunaan lokalitas atau warna lokal sebuah bahasa dalam hal ini bahasa daerah. Berdasarkan penjelasan tersebut, maka dapat dilihat bahwa bentuk dari lokalitas dalam kajian antropolinguitik itu tercermin dalam performance, yakni bagaimana seorang pengarang itu menggunakan bahasa dalam situasi komunikasi yang sebenarnya merupakan sistem bahasa yang dianut oleh pengarang tersebut. 


\section{Lokalitas sebagai wujud performace dalam karya sastra}

Johherf (dalam Yulianto, 2017) menyatakan bahwa lokalitas secara umum merupakan sebuah konsep umum, yang terkait dengan sekat geografis. Lokalitas dalam konsep budaya yang menurutnya bersifat fleksibel, dinamis, lentur, tidak kaku, dan mengacu pada kultur yang berlangsung di sebuah daerah. Lokalitas dalam sastra bukan hanya mengenai wilayah yang dibatasi atau berbatasan dengan wilayah lain yang secara fisik dapat diukur, tetapi mesti dimaknai dalam ranah budaya.

Menurut Yulianto (2017), secara struktural, lokalitas dalam sastra kerap dimaknai sebagai wilayah, tempat, kondisi, atau situasi dalam teks. Senada dengan itu, Ratna (2007), menyatakan bahwa lokalitas juga sama dengan warna lokal, yakni melukiskan ciri-ciri daerah tertentu. Warna lokal atau lokalitas berfungsi untuk menopang eksistensi geografi, luas wilayah Indonesia dengan keberagaman adat istiadat. Warna lokal atau lokalitas dapat juga berupa suasana tertentu isi cerita, muatan, dan permasalahan, bukan suatu kerangka pikiran, juga bukan suatu penceritaan secara keseluruhan. Di samping kualitas isi, meskipun ditulis dengan menggunakan bahasa Indonesia, warna lokal atau lokalitas juga memberikan sumbangan dalam bentuk bahasa lokal dengan dialek dan registernya (Ratna, 2007). Oleh karena itu, keberhasilan seorang penulis dalam membuat warna lokal atau mengangkat lokalitas bisa diukur dari diksi yang terpapar dalam sebuah karya sastra. Menurut Duranti (Simanjuntak, n.d. 2015), lokalitas dapat dilihat dari performance, yaitu penggunaan bahasa secara nyata dalam situasi komunikasi sebenarnya merupakan cerminan dari sistem bahasa yang ada pada pikiran penutur.

Oleh karena itu, dari pemaparan para ahli di atas untuk mengetahui warna lokal atau lokalitas dalam karya sastra pada sudut pandang bahasa diperlukan pemahaman kebudayaan dan bahasa dalam bangsa atau daerah pelaku cerita. Hal tersebut bertujuan untuk menciptakan fungsi estetis yang lebih konkret melalui makna langsung dan makna tidak langsung yang disampaikan oleh pengarang untuk menggambarkan warna lokal atau lokalitas yang terdapat dalam karyanya. Berdasarkan penjelasan tersebut, dapat dilihat bahwa bentuk dari lokalitas itu tercermin dalam performance, yakni bagaimana seorang pengarang itu menggunakan bahasa dalam situasi komunikasi yang sebenarnya merupakan sistem bahasa yang dianut oleh pengarang tersebut. Dalam novel Jemput Terbawa akan dilihat bagaimana bentuk kebahasaan yang digunakan oleh Pinto Anugrah dalam karyanya, yakni analisis performance yang berupa kata, frasa, klausa, dan kalimat. Oleh sebab itu, Chaer (2007) menyatakan bahwa kata adalah morfem atau kombinasi morfem yang oleh bahasawan dianggap sebagai satuan terkecil yang dapat diujarkan sebagai bentuk bebas, sedangkan frasa merupakan salah satu linguistik yang secara potensial merupakan gabungan dua kata atau lebih yang tidak mempunyai ciri-ciri, klausa, atau tidak melampaui batas subjek atau predikat. Lalu, klausa adalah satuan sintaksis yang bersifat predikatif dan kalimat adalah satuan bahasa terkecil yang dapat mengungkapkan pikiran yang utuh.

\section{Kebudayaan Minangkabau dalam Sudut Pandang Bahasa}

Menurut Zainuddin (2014), budaya Minangkabau banyak disamakan orang dengan adat Minangkabau, karena hal ini lumrah sebab dulunya adat ini disampaikan dari mulut ke mulut. Rahmat dan Maryelliwati (2019) menyatakan bahwa masyarakat Minangkabau menyebut wilayahnya dengan alam Minangkabau digambarkan sekitar Gunung Marapi, Gunung Sago, Gunung Singgalng, Gunung Talang, Gunung Kerinci, serta Gunung Pasaman. Batas wilayah minangkabau diperkirakan sebelah Utara Sikilaing Air Bangis, sebelah timur Taratak Air Hitam (indragiri), sebelah Selatan Sapucuak Jambi Sambilan Lurah, dan sebelah Barat Bengkulu dan indopuro.

Orang Minangkabau memiliki bahasa dan budaya yang berbeda-beda dari sekian etnis yang ada di Indonesia. Dalam berbahasa, orang Minangkabau memiliki bahasa yang disebut 
dengan bahasa Minangkabau digunakan dalam kehidupan sehari-hari. Rahmat dan Maryelliwati (2019) menyatakan bahwa bahasa Minangkabau adalah bahasa daerah yang berkembang di wilayah Sumatra Barat. Koentjaraningrat (1983) mengemukakan bahwa orang Minangkabau menggunakan suatu bahasa yang sama yakni, disebut dengan bahasa Minangkabau, sebuah bahasa tersendiri yang erat berhubungan dengan bahasa Melayu, tetapi dianggap hanya sebagai dialek saja.

Dari pemaparan di atas, dapat disimpulkan bahwa Minangkabau identik dengan bahasanya yang disebut bahasa Minangkabau. Dialek bahasa Minangkabau jika dilihat sekilas memang terdengar seperti bahasa Melayu. Bahasa Minangkabau digunakan oleh masyarakat yang mendiami wilayah bagian dari Minangkabau, karena hal ini, bahasa Minangkabau lebih banyak mengacu pada makna sosial kultural dan masyarakatnya yang mendiami wilayah administratif Sumatra Barat.

\section{METODE PENELITIAN}

Jenis penelitian yang dilakukan adalah jenis penelitian kualitatif. Metode yang digunakan dalam penelitian ini adalah metode analisis isi. Martono (2015) menjelaskan secara kualitatif metode analisis isi (content analysis) berupaya mengungkapkan makna di balik teks, symbol, atau materi tekstual lainnya dengan menganlisis secara kritis sebagai kepentingan atau muatan nilai-nilai tertentu yang mendasari pembentuk teks atau simbol- simbol tersebut. Proses penguraian dan penerangan itu dilanjutkan dengan inventarisasi. Data dalam penelitian ini berupa frasa, klausa, dan kalimat yang mengandung unsur lokalitas bahasa Minangkabau dalam novel Jemput Terbawa karya Pinto Anugrah. Sumber data dalam penelitian ini yaitu novel Jemput Terbawa karya Pinto Anugrah yang terbit pada tahun 2018, terdiri dari 206 halaman diterbitkan oleh Mojok.

Pengumpulan data dalam penelitian ini menggunakan metode simak. Menurut Sudaryanto (1993), disebut metode simak atau penyimakan karena memang berupa penyimakan penggunaan bahasa. Teknik yang digunakan dalam dalam metode simak adalah teknik catat. Teknik analisis data dalam penelitian ini menggunakan metode padan dan agih. Menurut Sudaryanto (1993), metode padan adalah alat penentunya di luar dan tidak menjadi bagian dari bahasa (langue) yang bersangkutan dan metode agih adalah alat justru yang berasal dari bahasa itu sendiri. Metode padan yang digunakan adalah padan referensial dan pragmatis. Padan referensial adalah kenyataan atau segala sesuatu (yang bersifat luar bahasa) yang ditunjuk oleh bahasa. Lalu, padan pragmatis adalah alat penentu berupa makna. Metode agih yang digunakan adalah lesap dan agih. Teknik lesap dilaksanakan dengan melesapkan unsur tertentu. Teknik ganti dilaksanakan dengan mengganti unsur tertentu satuan lingual yang bersangkutan dengan unsur tertentu yang lain di luar satuan lingual yang bersangkutan. Selain itu, analisis data juga dibantu dengan menggunakan teknik baca markah. Sudaryanto (1993) menyatakan baca markah salah satu teknik analisis data.

\section{PEMBAHASAN}

Berdasarkan hasil penelitian, ditemukan bentuk-bentuk lokalitas dalam novel Jemput Terbawa karya Pinto Anugrah melalui performance yakni kata, frasa, dan klausa. Berikut ini akan dijelaskan temuan data lokalitas dalam novel Jemput Terbawa karya Pinto Anugrah.

\section{Lokalitas dalam Novel Jemput Terbawa Karya Pinto Anugrah Berupa Kata Kerja, Kata Benda, dan Kata Sifat}

Performance merupakan penggunaan bahasa secara nyata dalam situasi komunikasi yang sebenarnya merupakan cerminan dari sistem bahasa yang ada pada pikiran penutur. Penutur yang dimaksud ialah seorang pengarang yang bernama Pinto Anugrah. Berikut akan 
dijelaskan analisis lokalitas berupa kata yang terdapat dalam novel Jemput Terbawa karya Pinto Anugrah.

Data 1

.... Lantunan dendang dan gesekan rebab seketika berhenti. Anugrah (2018:1)

Data 1 di atas merupakan bentuk dari lokalitas Minangkabau dalam novel Jemput Terbawa karya Pinto Anugrah. Berdasarkan pendapat Simanjuntak (2015) performance sebagai bentuk lokalitas dalam novel Jemput Terbawa karya Pinto Anugrah yakni berupa kata dendang. Kata dendang dalam novel ini merupakan bahasa Indonesia yang merujuk ke bahasa Minangkabau dengan sebutan yang sama. Rahmat (2016) menyatakan dalam sastra lisan ketika pendendang menyampaikan kaba, dendang merupakan tuturan masyarakat Minangkabau yang dapat didengar, yakni dendang ka dimulai, maksudnya adalah dendang akan segera dimulai. Jadi makna kata dendang ialah sebuah nyanyian untuk mengungkapkan berbegai jenis perasaan seperti sedih, senang, duka, dan sebagainya yang diiringi dengan gesekan bunyi rabab, dendang juga merupakan ciri khas kesenian di Minangkabau. Dengan demikian, dendang ini dapat dijumpai ketika adanya pesta pernikahan yang orang Minang sebut baralek dan juga acara adat di Minangkabau. Pada zaman dahulu, keluarga kerajaan di Minang mewariskan ilmu dari generasi ke generasi yang bisa disebut dengan ilmu hitam. Jika keluarga itu mengadakan sebuah acara baralek dengan menghadirkan dendang dan rabab, utusan dari ilmu itu akan muncul. Pihak keluarga akan menyediakan sesajian berupa makanan dan utusan yang dimaksud bisa berupa harimau dan buaya. Kata dendang ini merupakan cerminan potret sosial budaya masyarakat yang beretnis Minang dan menjadikannnya sebuah upaya untuk mengungkapkan kearifan lokal yang menjadi keunikan dalam sebuah kebudayaan yang bisa tergambar dari bahasanya. Hal ini sesuai dengan pendapat Sitompul dan Simaremar (2017) yang menyebutkan bahwa memahami sebuah teks dapat menggali dan mencerminkan sebuah nilai, norma, dan kearifan lokal.

Pinto Anugrah sebagai penutur yang beretnis Minang menyatakan bahwa dendang itu merupakan sebuah nyanyian yang bisa menyejukan dan menyayat hati sekaligus. Hal ini terlihat dalam isi novel yang diceritakan kepada pembaca sebagai mitra tutur. Kata dendang jika dilesapkan dalam kalimat "lantunan dendang dan gesekan rebab seketika berhenti", kalimat tersebut akan berubah makna. Pernyataan tersebut dapat dilihat pada analisis berikut.

Data 1.a lantunan dendang dan gesekan rebab seketika berhenti

Data 1.b lantunan dan gesekan rebab seketika berhenti

Berdasarkan analisis di atas, maka dapat dibuktikan bahwa pemarkah lokalitas dalam novel Jemput Terbawa karya Pinto Anugrah adalah benar adanya. Hal ini dibuktikan jika diterapkan teknik lesap, maka ia akan berubah makna.

Data 2

.... Lantunan dendang dan gesekan rebab seketika berhenti. Anugrah (2018:1)

Data 2 di atas merupakan bentuk dari lokalitas Minangkabau dalam novel Jemput Terbawa karya Pinto Anugrah. Berdasarkan pendapat Simanjuntak (2015) performance sebagai bentuk lokalitas dalam novel Jemput Terbawa karya Pinto Anugrah yakni berupa kata rabab. Kata rebab dalam novel ini merujuk pada bahasa Minangkabau yakni rabab. Rusmali dkk (1985) menyatakan bahwa rebab adalah alat musik tradisional yang terbuat dari tempurung dan hampir mirip dengan biola. Jadi makna rebab atau rabab dalam konteks budaya Minangkabau merupakan sebuah alat musik gesek tradisional Minangkabau yang terbuat dari tempurung kelapa. Di Minangkabau, rebab dan dendang adalah dua hal yang saling berkaitan. Hal ini dapat dilihat ketika adanya suatu pesta pernikahan yang disebut baralek oleh orang Minang yang biasanya diadakan pada Sabtu malam akan dimeriahkan oleh rabab. Semua anggota pemain 
rabab akan bersama-sama menggesekan rababnya dan berdendang untuk menyampaikan rasa gembira maupun rasa duka. Kata rebab atau rabab ini merupakan cerminan sosial budaya masyarakat yang beretnis Minang dan menjadikannnya sebuah upaya untuk mengungkapkan kearifan lokal yang menjadi keunikan dalam sebuah kebudayaan yang bisa tergambar dari bahasanya. Hal ini sesuai dengan pendapat Sitompul dan Simaremar (2017) yang menyebutkan bahwa memahami sebuah teks dapat menggali dan mencerminkan sebuah nilai, norma, dan kearifan lokal.

Pinto Anugrah sebagai penutur yang beretnis Minang menyatakan bahwa rebab adalah alat musik gesek yang dimainkan bersama nyanyian-nyanyian dendang. Dengan demikian, hal ini terlihat dari isi novel yang diceritakan kepada pembaca sebagai mitra tutur. Kata rebab jika dilesapkan dalam kalimat "lantunan dendang dan gesekan rebab seketika berhenti", kalimat tersebut akan berubah makna. Pernyataan tersebut dapat dilihat pada analisis berikut.

Data 2.a lantunan dendang dan gesekan rebab seketika berhenti

Data 2.b lantunan dendang dan gesekan seketika berhenti

Berdasarkan analisis di atas, maka dapat dibuktikan bahwa pemarkah lokalitas dalam novel Jemput Terbawa karya Pinto Anugrah adalah benar adanya. Hal ini dibuktikan jika diterapkan teknik lesap, ia akan berubah makna.

Data 3

....Pintu yang tirainya sudah begitu lusuh entah sudah berapa tahun tidak diganti ataupun di cuci- ia singkap, ragu-ragu, matanya mengintip ke dalam. Anugrah (2018:7)

Data 3 di atas merupakan bentuk dari lokalitas Minangkabau dalam novel Jemput Terbawa karya Pinto Anugrah. Berdasarkan pendapat Simanjuntak (2015) performance sebagai bentuk lokalitas dalam novel Jemput Terbawa karya Pinto Anugrah yakni berupa kata lusuah. Kata lusuah dalam novel ini merujuk pada bahasa Minangkabau yakni lusuah. Rusmali dkk (1985) menyatakan bahwa kata lusuah digunakan untuk menyatakan kondisi pakaian seseorang, seperti bajunyo lah lusuh, maksudnya adalah bajunya sudah lusuh. Jadi makna lusuh atau lusuah dalam konteks budaya Minangkabau merupakan kata untuk menyatakan sebuah kondisi benda yang sudah tidak layak pakai lagi, hal ini terlihat pada masyarakat Minangkabau. Jika ada benda atau pakaian yang sudah sangat jauh ketinggalan zaman dan tidak layak pakai, masyarakat Minangkabau akan menyebutnya "lusuh atau lusuah". Hal ini merupakan cerminan potret sosial budaya masyarakat yang beretnis Minang dan menjadikannnya sebuah upaya untuk mengungkapkan kearifan lokal yang menjadi keunikan dalam sebuah kebudayaan yang bisa tergambar dari bahasanya. Hal ini sesuai dengan pendapat Sitompul dan Simaremar (2017) yang menyebutkan bahwa memahami sebuah teks dapat menggali dan mencerminkan sebuah nilai, norma, dan kearifan lokal.

Pinto Anugrah sebagai penutur yang beretnis Minang menyatakan bahwa kata lusuh merupakan keterangan suatu benda yakni tirai yang sudah begitu kusam tak layak pakai lagi. Ia menyampaikannya dalam isi novel yang diceritakan kepada pembaca sebagai mitra tutur. Kata lusuh (lusuah) jika dilesapkan dalam kalimat "Pintu yang tirainya sudah begitu lusuh entah sudah berapa tahun tidak diganti ataupun di cuci- ia singkap, ragu-ragu, matanya mengintip ke dalam", kalimat tersebut akan berubah makna. Pernyataan tersebut dapat dilihat pada analisis berikut.

Data 3.a Pintu yang tirainya sudah begitu lusuh entah sudah berapa tahun tidak diganti ataupun di cuciia singkap, ragu-ragu, matanya mengintip ke dalam.

Data 3.b Pintu yang tirainya sudah begitu entah sudah berapa tahun tidak diganti ataupun di cuci- ia singkap , ragu-ragu, matanya mengintip ke dalam.

Berdasarkan analisis diatas, maka dapat dibuktikan bahwa pemarkah lokalitas dalam novel Jemput Terbawa karya Pinto Anugrah adalah benar adanya. Hal ini dibuktikan jika 
diterapkan teknik lesap dalam penanda tersebut, pemarkah itu akan mengubah makna dari data tersebut.

\section{Lokalitas dalam Novel Jemput Terbawa Karya Pinto Anugrah Berupa Frasa Nomina}

Performance merupakan penggunaan bahasa secara nyata dalam situasi komunikasi yang sebenarnya merupakan cerminan dari sistem bahasa yang ada pada pikiran penutur. Penutur yang dimaksud ialah seorang pengarang yang bernama Pinto Anugrah. Berikut akan dijelaskan analisis lokalitas berupa frasa yang terdapat dalam novel Jemput Terbawa karya Pinto Anugrah.

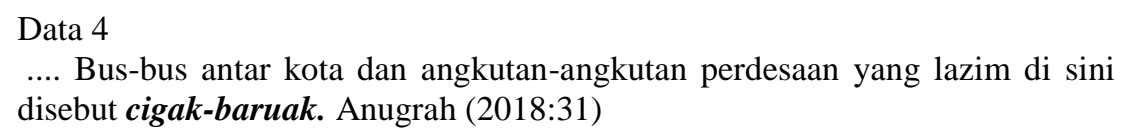

Data 4 di atas merupakan bentuk dari lokalitas Minangkabau dalam novel Jemput Terbawa karya Pinto Anugrah. Performance sebagai bentuk lokalitas dalam novel Jemput Terbawa karya Pinto Anugrah yakni berupa frasa cigak baruak. Frasa cigak baruak dalam novel ini merupakan bahasa Minangkabau. Rusmadi (1985) menyatakan bahwa cigak baruak adalah seekor beruk. Akan tetapi, makna cigak baruak dalam konteks budaya Minangkabau merupakan suatu pernyataan sebuah benda yang sudah jauh ketinggalan zaman seperti mobil lama dengan kondisi yang tak layak pakai lagi. Pada umumnya masyarakat Minangkabau menggunakan frasa cigak baruak ini hanya untuk alat transportasi berupa mobil, maka munculah frasa cigak baruak ini yang diujarkan oleh masyarakat setempat di Minangkabau. Hal ini merupakan cerminan potret sosial budaya masyarakat yang beretnis Minang dan menjadikannya sebuah upaya untuk mengungkapkan kearifan lokal yang menjadi keunikan dalam sebuah kebudayaan yang bisa tergambar dari bahasanya. Hal ini sesuai dengan pendapat Sitompul dan Simaremar (2017) yang menyebutkan bahwa memahami sebuah teks dapat menggali dan mencerminkan sebuah nilai, norma, dan kearifan lokal.

Pinto Anugrah sebagai penutur yang beretnis Minang juga menyatakan bahwa cigak baruak adalah sebuah label yang digunakan untuk menyatakan sebuah benda yang sudah ketinggalan zaman seperti mobil. Hal ini terlihat dari isi novel yang diceritakan kepada pembaca sebagai mitra tutur. Frasa cigak baruak jika dilesapkan dalam kalimat "Bus-bus antarkota dan angkutan-angkutan perdesaan yang lazim di sini disebut cigak-baruak", kalimat tersebut akan berubah makna. Pernyataan tersebut dapat dilihat pada analisis berikut.

Data 4.a Bus-bus antar kota dan angkutan-angkutan perdesaan yang lazim di sini disebut cigak-baruak

Data 4.b Bus-bus antar kota dan angkutan-angkutan perdesaan yang lazim di sini disebut

Berdasarkan analisis di atas, maka dapat dibuktikan bahwa pemarkah lokalitas dalam novel Jemput Terbawa karya Pinto Anugrah adalah benar adanya. Hal ini dibuktikan jika diterapkan teknik lesap dalam penanda tersebut, pemarkah itu akan mengubah makna dari data tersebut.

Data 5

.... Di bawah sepasang pakaian itu terdapat sehelai selendang berwarna putih yang sudah kusam pula, lalu baju kurung berwarna tanah liat serta sehelai kain sampin panjang. Anugrah (2018:48)

Data 5 di atas merupakan bentuk dari lokalitas Minangkabau dalam novel Jemput Terbawa karya Pinto Anugrah. Bentuk performance sebagai bentuk lokalitas dalam novel Jemput Terbawa karya Pinto Anugrah yakni berupa frasa baju kurung. Frasa baju kurung dalam novel ini merujuk pada bahasa Minangkabau yakni baju kuruang. Menurut Rahmat (2012) baju 
kurung adalah pakaian sehari-hari wanita Minangkabau. Jadi makna baju kurung atau baju kuruang dalam konteks budaya Minangkabau merupakan pakaian sehari-hari wanita di Minangkabau yang mana bajunya terbuat dari kain yang di jahit sampai lutut dan bawahannya adalah rok. Baju kuruang dipakai oleh wanita Minang agar dapat menutupi auratnya. Hal ini dilihat berdasarkan landasan budaya Minangkabau dari zaman dahulunya hingga saat ini yang berbunyi "adat basandi syarak, syarak basandi kitabullah". Dengan demikian, adat di Minang berdasarkan agama Islam karena pada umumnya orang Minang beragama Islam. Islam mengajarkan bahwa seorang wanita ataupun anak-anak perempuan diwajibkan untuk menutupi auratnya. Baju kuruang merupakan salah satu hal yang diwajibkan untuk digunakan dalam masyarakat Minangkabau karena sesuai syariat agama Islam. Berdasarkan hal tersebut, baju kuruang merupakan cerminan sosial budaya masyarakat yang beretnis Minang dan menjadikannya sebuah upaya untuk mengungkapkan kearifan lokal yang menjadi keunikan dalam sebuah kebudayaan yang bisa tergambar dari bahasanya. Hal ini sesuai dengan pendapat Sitompul dan Simaremar (2017) yang menyebutkan bahwa memahami sebuah teks dapat menggali dan mencerminkan sebuah nilai, norma, dan kearifan lokal.

Pinto Anugrah sebagai penutur yang beretnis Minang menyatakan bahwa baju kurung adalah pakaian yang digunakan bersama selendang oleh seorang wanita di Minangkabau. Hal ini terlihat dari isi novel yang diceritakan kepada pembaca sebagai mitra tutur. Frasa baju kurung atau baju kuruang jika dilesapkan dalam kalimat "Di bawah sepasang pakaian itu terdapat sehelai selendang berwarna putih yang sudah kusam pula, lalu baju kurung berwarna tanah liat serta sehelai kain sampin panjang", kalimat tersebut akan berubah makna. Pernyataan tersebut dapat dilihat pada analisis berikut.

Data 5.a Di bawah sepasang pakaian itu terdapat sehelai selendang berwarna putih yang sudah kusam pula, lalu baju kurung berwarna tanah liat serta sehelai kain sampin panjang.

Data 5.b Di bawah sepasang pakaian itu terdapat sehelai selendang berwarna putih yang sudah kusam pula, lalu berwarna tanah liat serta sehelai kain sampin panjang.

Berdasarkan analisis di atas, maka dapat dibuktikan bahwa pemarkah lokalitas dalam novel Jemput Terbawa karya Pinto Anugrah adalah benar adanya. Hal ini dibuktikan jika diterapkan teknik lesap dalam penanda tersebut, pemarkah itu akan mengubah makna dari data tersebut.

\section{Lokalitas dalam Novel Jemput Terbawa Karya Pinto Anugrah Berupa Klausa}

Klausa adalah satuan sintaksis yang bersifat predikatif dan kalimat adalah satuan bahasa terkecil yang dapat mengungkapkan pikiran yang utuh (Chaer, 2007). Oleh sebab itu, pada bagian berikut akan dijelaskan analisis lokalitas berupa klausa yang terdapat dalam novel Jemput Terbawa karya Pinto Anugrah.

Data 6

... Rebab jua yang kan menyampaikan, Nak oi...

Dendang orang itu sambil menggesekkan rebabnya. Anugrah (2018:84)

Data 6 di atas merupakan bentuk dari lokalitas Minangkabau dalam novel Jemput Terbawa karya Pinto Anugrah. Bentuk performance sebagai bentuk lokalitas dalam novel Jemput Terbawa karya Pinto Anugrah yakni berupa klausa "Rebab jua yang kan menyampaikan, Nak oi...". Klausa "Rebab jua yang kan menyampaikan, Nak oi...” dalam novel ini merujuk pada bahasa Minangkabau yakni "rabab juo nan kamanyampaian, nak oi". Rusmali dkk (1985) menyatakan bahwa rabab atau rebab adalah alat musik tradisional yang terbuat dari tempurung dan hampir sama dengan biola. Jadi makna "Rebab jua yang kan menyampaikan, Nak oi..." dalam konteks budaya Minangkabau merupakan klausa untuk 
menyatakan sebuah perasaan yang terpendam, seperti ketika keluarga pada masyarakat Minangkabau yang tengah merantau melepaskan rindu, hanya rabablah yang bisa menyampaikan segala hal yang dirasakan oleh orang tersebut. Pada umumnya, rabab adalah sebuah alat musik tradisional Minangkabau yang apabila dimainkan akan diiringi dendangdendang yang begitu menyayat relung hati paling dalam. Hal ini merupakan cerminan potret sosial budaya masyarakat Minang dan upaya untuk mengungkapkan kearifan lokal yang menjadi keunikan dalam sebuah kebudayaan yang bisa tergambar dari bahasanya. Hal ini sesuai dengan pendapat Sitompul dan Simaremar (2017) yang menyebutkan bahwa memahami sebuah teks dapat menggali dan mencerminkan sebuah nilai, norma, dan kearifan lokal.

Pinto Anugrah sebagai penutur yang beretnis Minang menyatakan hanya rabablah yang bisa menyampaikan maksud hati yang terpendam. Dengan demikian, hal ini terlihat dari isi novel yang diceritakan kepada pembaca sebagai mitra tutur. Klausa "Rebab jua yang kan menyampaikan, Nak oi..." jika dilesapkan dalam kalimat "Rebab jua yang kan menyampaikan, Nak oi... dendang orang itu sambil menggesekkan rebabnya", kalimat tersebut akan berubah makna. Pernyataan tersebut dapat dilihat pada analisis berikut.

Data 6.a Rebab jua yang kan menyampaikan, Nak oi...dendang orang itu sambil menggesekkan rebabnya.

Data 6.b dendang orang itu sambil menggesekkan rebabnya.

Berdasarkan analisis diatas, maka dapat dibuktikan bahwa pemarkah lokalitas dalam novel Jemput Terbawa karya Pinto Anugrah adalah benar adanya. Hal ini dibuktikan jika diterapkan teknik lesap, ia akan berubah makna.

Berdasarkan tiga bentuk temuan di atas, maka dapat disimpulkan bahwa sebuah novel yang menghadirkan bahasa lokal atau bahasa daerah merupakan karya sastra yang memiliki unsur keindahan tersendiri. Pinto Anugrah seorang pengarang yang beretnis Minangkabau yang lahir di Sungai Tarab Batusangkar menggunakan bahasa Minangkabau dalam karyanya atau yang disebut lokalitas untuk menyampaikan maksud tertentu dalam karyanya. Lokalitas dalam novel Jemput Terbawa tersebut menggambarkan kebahasaan dan realita masyarakat Minangkabau pada zamannya. Minangkabau adalah sebuah negeri dimana segala sesuatunya disampaikan dengan bahasa yang memikat, seperti pantun dan petatah petitih yang disampaikan melalui dendang dan rabab.

Penggunaan bahasa yang disebut dengan lokalitas dapat menggambarkan potret sosial budaya, sehingga ditemukan leksikal-leksikal bahasa Indonesia yang merujuk ke bahasa Minang yang berupa kata, frasa, dan klausa. Pada dasarnya, maksud Pinto Anugrah memakai lokalitas Minangkabau dalam novel Jemput Terbawa ini untuk mengungkapkan bahwa masih banyak kosakata Minangkabau yang unik dan menarik. Hal ini dapat menjadi suatu bentuk identitas masyarakat Minangkabau, meskipun banyak kosakata dalam bahasa Minangkabau yang sudah diindonesiakan. Dengan demikian, meskipun sebagian masyarakat Minangkabau sudah menganut paham modern, hal ini masih terlihat sampai sekarang di lingkungan masyarakat Minangkabau. Saat ini, sangat sedikit masyarakat Minangkabau yang rumahnya berbentuk rumah gadang seperti dahulu. Namun, sistem keturunan yang dianut masyarakat Minang saat ini masih sistem Matrilineal. Hal ini dapat dilihat pada kutipan yang ada dalam novel Jemput Terbawa, yaitu "Di sini kita bersuku ibu”. Ungkapan tersebut menyatakan bahwa seseorang akan mengikuti suku yang dipakai oleh ibunya. Di Minangkabau, seorang ibu yang mampu membimbing anak-anaknya dan mengatur segala hal menjadi baik akan mendapatkan panggilan khusus, seperti kutipan dalam novel Jemput Terbawa karya Pinto Anugrah yang berbunyi Bundo kanduang.

Dalam novel Jemput Terbawa bentuk lokalitas yang paling banyak adalah kata sifat, kata benda, dan kata keterangan yang menggambarkan keadaan masyarakat dalam lingkungan Minangkabau. Keadaan yang dapat dilihat melalui kutipan dibawah ini. 


\author{
Di langit terberita \\ Di bumi menjadi kaba \\ Kisah orang kami kabarkan \\ Dusta orang kami tidak ikut serta
}

Ungkapan tersebut menggambarkan bahwa masyarakat Minangkabau untuk menanyakan sebuah kabar dengan menggunakan kata kaba. Minangkabau merupakan wilayah yang sangat kental dengan adat dan kebudayaan. Tidak hanya itu, kedua hal tersebut berlandaskan pada agama yang dianut oleh masyarakat Minang yang pada umumnya beragama islam, sehingga dijadikan sebagai landasan dalam berbuat dan bertingkah laku di kehidupan sehari-hari. Masyarakat Minangkabau di kenal sebagai masyarakat yang religius. Sebagaimana yang dapat dilihat dari pepatah Minang yang berbunyi "adat basandi syarak, syarak basandi kitabullah" yang dapat diartikan sebagai keseimbangan antara adat dan agama. Oleh sebab itu, hubungan islam dan Minangkabau ini harus dipelajari dan diajarkan kepada generasi penerus masyarakat Minangkabau yang mencintai asal-usulnya khususnya bahasa Minangkabau.

\title{
PENUTUP
}

Performance merupakan penggunaan bahasa secara nyata dalam situasi komunikasi yang sebenarnya, yang juga merupakan cerminan dari sistem bahasa yang ada pada pikiran penutur sebagai bentuk lokalitas. Hal ini dapat berupa kata kerja, kata benda, dan kata sifat, sedangkan pada tataran frasa yakni pada frasa nomina dan klausa objek berdasarkan fungsinya. Penggunaan bentuk lokalitas oleh Pinto Anugrah pada karyanya yang berupa sebuah novel merupakan salah satu aspek yang cukup penting. Hal ini akan lebih menekankan bahwa pengarang ingin menyampaikan suatu maksud melalui bahasa lokal yang ia sampaikan dalam karyanya, yakni pemahaman struktur teks dan konteks dalam sebuah teks dapat memberikan pemahaman tentang bentuk kebudayaan yang dimiliki suatu komunal masyarakat seperti nilai, norma, dan kearifan lokal. Selain itu, dapat menggambarkan pula bahwa kreativitas penutur dalam teks merupakan cara untuk terus mempertahankan dan menemukan keunikan dibalik setiap karya yang dihasilkan oleh pengarang.

\section{DAFTAR PUSTAKA}

Anugrah, Pinto. (2018). Jemput Terbawa. Yogyakarta: Buku Mojok.

Chaer, Abdul. 2002. Pengantar Semantik Bahasa Indonesia. Jakarta: Rineka Cipta.

Koentjaraningrat. (1983). Manusia dan Kebudayaan di Indonesia. Jakarta: Djambatan.

Lubis, T. (2019). Tardisi Lisan Nandong Simeulue Pendekatan Antropolinguistik. In S3 Linguistik. Universitas Sumatera Utara. https://doi.org/10.31227/osf.io/kv47c

Martono, Nanang. (2015). Metode Penelitian sosial: Konsep-konsep kunci. Jakarta: PT Raja Grafindo Persada.

Noortayanti, Jumadi Zulkifli Rusma. (2017). Antropolingustik dalam Mantra Dayak Maanyan di Kalimantan Selatan. Jurnal Bahasa, Sastra dan Pembelajarannya. 7(1) 35-49. https://doi.org/10.20527/jbsp.v7i1.3765

Rahmat, W. (2012). Sosial Budaya Cina Dalam Kaba Siti Kalasun, Tinjauan Sosiologi Sastra. Universitas Andalas. https://doi.org/10.22216/jit.2016.v10i4.579

Rahmat, W. (2016). Penerapan Kaba Minangkabau Sebagai Media Pelestarian Bahasa Amai (Ibu) dan Kesusastraan dalam Pendidikan Literasi di Minangkabau. Jurnal Ipteks Terapan, 10(4), 236-241. https://doi.org/10.22216/jcc.2019.v4i2.4218

Rahmat, W., Revita, I., \& Fitriyah, R. (2019). Psychopragmatic Analysis in Language Learning and Teaching Processes. Curricula, 4(2), 92. http://ejournal.1ldikti10.id/index.php/curricula/article/view/4218

Rahmat, W., \& Maryelliwati, M. (2019). Minangkabau (Adat, Bahasa, Sastra dan Bentuk 
Penerapan). Padang: STKIP PGRI Press.

Ratna, Nyoman Kutha. (2007). Sastra dan Cultural Studies. Yogyakarta: Pustaka Pelajar.

Revita, I., Trioclarise, R., \& Anggreiny, N. (2019). Psychopragmatic Analysis of Speech Act of The Perpetrators of The Violence Toward Minangkabau Women Analisis Psikopragmatik Tindak Tutur Pelaku Kekerasan Terhadap Perempuan Minangkabau. Jurnal Gramatika: Jurnal Penelitian Pendidikan Bahasa dan Sastra Indonesia, 1(1962), $112-121$.

Rinaldi, R. (2018). Retorik Lokalitas Minangkabau dalam Novel-novel Romantisisme Pengarang Etnis Minangkabau: Perspektif Stilistik-Antropolingustik. dalam Seminar Internasional Riksa Bahasa XII. 691--700. http://proceedings.upi.edu/index.php/riksabahasa/article/view/195/187

Rusmali, Marah dkk. (1985). Kamus Minangkabau-Indonesia. Jakarta: Pusat Pembinaan dan Pengembangan Bahasa Departemen Pendidikan dan Kebudayaan.

Semi, M. Atar. (2002). Stilistika Sastra. Padang: UNP Press.

Sibarani, R. (2015). Pendekatan Antropolingustik terhadap Kajian Tradisi Lisan. Retorika, 1(1), 1-17. https://doi.org/10.22225/jr.v1i1.9

Simanjuntak, D. S. R. (2015). Penerapan Teori Antropolingustik Modren (Competence, Performance, Indexicality, dan Partisipation) dalam Umpasa Budaya Batak Toba. Jurnal Basis UPB. 2(2). http://113.212.163.133/index.php/basis/article/view/407

Sitompul, E. A., \& Simaremar, J. A. (2017). Analisis Fungsi, Nilai Budaya dan Kearifan Lokal dalam Film Sinamot Karya Sineas Muda Medan: Kajian Antropolinguistik. Suluh Pendidikan, 4(2), 24-37. http://jsp.uhn.ac.id/wp-content/uploads/2018/03/04-JurnalEden-Sitompul.pdf

Yulianto, A. (2017). Unsur-unsur Lokalitas dalam Novel Galuh Hati Karya Randu Alamsyah. Kandai, 13(1), 61-74. https://doi.org/10.26499/jk.v13i1.158

Zainuddin, Musyair. (2014). Ranah Minang. Padang: Ombak 